\title{
Pendekatan Pemrograman Linier untuk Menyelesaikan Masalah Farm Planning
}

\author{
Ramya Rachmawati, Siska Yosmar ${ }^{1}$
}

\begin{abstract}
Abstrak
Pemrograman Linier merupakan pendekatan yang efektif untuk menyelesaikan masalah optimasi pengalokasian sumber daya yang terbatas. Dari berbagai literatur, dapat diketahui bahwa pendekatan ini telah sukses diterapkan di berbagai bidang, termasuk bidang pertanian dan peternakan. Penelitian ini mengembangkan sebuah model Pemrograman Linier tentang bagaimana seorang manajer yang bergerak di bidang pertanian/peternakan dapat mengelola lahan dan komoditas ternak sapi yang tersedia sehingga menghasilkan keuntungan yang maksimum selama periode waktu perencanaan. Simulasi model dalam penelitian ini dilakukan dengan menggunakan bahasa pemrograman Python 2.7 dan PuLP modeller.
\end{abstract}

\section{Kata Kunci: Pemrograman Linier, Optimisasi, Perencanaan pertanian, Peternakan sapi}

\section{Pendahuluan}

\subsection{Latar Belakang}

Pemrograman Linier (PL) merupakan pendekatan matematis yang sudah banyak diterapkan dengan sukses di berbagai bidang, termasuk bidang pertanian/peternakan (Hillier and Lieberman, 2005). Esensi dari pendekatan PL ini adalah bagaimana mengalokasikan sumber daya yang terbatas di antara aktivitas-aktivitas yang saling bersaing untuk memperoleh hasil yang optimal. Pendekatan ini sudah terbukti mampu menghemat biaya bagi banyak perusahaan pertanian/peternakan.

Penelitian ini akan berfokus pada bagaimana seorang peternak, khususnya peternak sapi, dapat mengelola lahan pertanian yang dia miliki untuk mengoptimalkan keuntungan selama periode waktu tertentu. Keuntungan tersebut dapat diperoleh dari penjualan komoditas yang ada pada lahan pertaniannya, seperti anak sapi, sapi dewasa, susu sapi, juga hasil penjualan tanaman sebagai pakan ternak sapi yang ditanam di lahan tersebut.

Peternak sapi tersebut dihadapkan pada berbagai masalah sumber daya yang terbatas, di antaranya adalah keterbatasan lahan, tenaga kerja dan modal yang dia miliki. Dia juga dihadapkan pada berbagai pilihan seperti apakah harus menanam sendiri tanaman untuk mencukupi kebutuhan pangan sapi-sapinya, ataukah harus membeli pakan ternak dari petani lain. Tingkat kesuburan tanah pada sebuah lahan pertanian bisa jadi berbeda-beda, yang akan berdampak pada hasil panen yang berbeda pula. Dia juga harus menentukan kapan waktu yang tepat untuk menjual sapi-sapinya ataukah memelihara sapi untuk diperah susunya. Tentunya,

\footnotetext{
${ }^{1}$ Jurusan Matematika, Fakultas Matematika dan Ilmu Pengetahuan Alam Universitas Bengkulu ramya.rachmawati@unib.ac.id, siska.yosmar@unib.ac.id
} 


\section{Ramya Rachmawati, Siska Yosmar}

sapi yang dapat diperah susunya adalah sapi dengan usia cukup matang, sekitar 1,5 tahun (Sudono et al., 2003).

Selama ini, kebanyakan dari peternak menjalankan usahanya berdasarkan intuisi. Penelitian ini akan mengembangkan sebuah model PL sebagai acuan bagi para peternak sapi untuk memperoleh keuntungan yang maksimal. Pertanyaan utama yang akan dijawab adalah bagaimana melakukan perencanaan dalam sektor pertanian/peternakan untuk memaksimalkan profit.

\subsection{Tujuan Penelitian}

Penelitian ini bertujuan untuk mengembangkan model guna memaksimumkan keuntungan di sektor peternakan, khususnya peternakan sapi selama periode perencanaan. Pendekatan pemrograman linier akan digunakan untuk menentukan solusi optimal.

\subsection{Metode Penelitian}

Penelitian ini merupakan studi literatur. Sumber yang digunakan dalam penelitian ini adalah jurnal dan buku teks. Adapun tahapan yang dilakukan dalam penelitian ini adalah:

1. Mengumpulkan literatur dalam bidang pertanian dan peternakan yang relevan.

2. Mengembangkan model dengan pendekatan pemrograman linier.

3. Melakukan simulasi menggunakan bahasa pemrograman Python 2.7, dengan PuLP modeller.

4. Menarik kesimpulan.

\section{Formulasi Model}

Model Pemrograman Linier dalam makalah ini dibangun berdasarkan penelitian terdahulu, Williams (2013), sebagai berikut.

Misalkan seorang peternak memiliki 200 acre lahan. Ia merencanakan pengelolaan lahan tersebut untuk sepuluh tahun ke depan. Saat ini, ia memiliki 120 sapi betina, dengan perincian 100 ekor sapi perah dan 20 sapi betina muda. Setiap sapi betina muda memerlukan 2/3 acre lahan dan setiap sapi perah memerlukan 1 acre.

Sapi perah memproduksi rata-rata 1,1 anak sapi per tahun. Setengah dari anak-anak sapi tersebut adalah anak sapi jantan, yang langsung dijual dengan harga \$45. Sisa dari anak sapi tersebut, yang merupakan anak sapi betina, bisa dijual dengan harga $\$ 60$, atau dapat juga dipelihara menjadi sapi perah yang dapat menghasilkan susu pada saat usianya dua tahun. Semua sapi perah direncanakan akan dijual saat usianya mencapai 12 tahun dengan harga $\$ 180$ per sapi perah, walaupun bisa saja terjadi 5\% penyusutan (tingkat kematian) tahunan untuk sapi muda betina dan $2 \%$ penyusutan (tingkat kematian) tahunan untuk sapi perah. Saat ini, terdapat masing-masing 10 sapi yang berusia 0 sampai 11 tahun.

Susu yang diproduksi seekor sapi perah menghasilkan keuntungan tahunan sebesar \$555. Saat ini, sapi yang bisa dikandangkan adalah paling banyak 130 sapi. Jika sapi yang dipelihara ternyata lebih dari 130 sapi, maka biaya akomodasi yang diperlukan untuk tiap kelebihan sapi adalah sebesar $\$ 300$ tiap sapi. Setiap sapi perah membutuhkan $600 \mathrm{~kg}$ grain dan 


\section{Ramya Rachmawati, Siska Yosmar}

$700 \mathrm{~kg}$ sugar beet tiap tahun. Grain dan sugar beet tersebut dapat ditanam di lahan tersebut. Setiap acre lahan menghasilkan $1500 \mathrm{~kg}$ sugar beet. Hanya 80 acre lahan yang cocok ditanami grain. Lahan tersebut bisa dibagi empat kelompok dengan hasil sebagai berikut:

\begin{tabular}{lll}
\hline Grup 1 & 20 acre & $1100 \mathrm{~kg}$ tiap acre \\
Grup 2 & 30 acre & $900 \mathrm{~kg}$ tiap acre \\
Grup 3 & 20 acre & $800 \mathrm{~kg}$ tiap acre \\
Grup 4 & 10 acre & $650 \mathrm{~kg}$ tiap acre \\
\hline
\end{tabular}

Grain dapat dibeli seharga $\$ 135$ per ton dan dijual seharga $\$ 112.5$ per ton. Sugar beet dapat dibeli seharga $\$ 105$ per ton dan dijual seharga $\$ 87$ per ton.

Kebutuhan tenaga kerja adalah sebagai berikut:

\begin{tabular}{ll}
\hline Tiap sapi muda & 10 jam per tahun \\
Tiap sapi perah & 42 jam per tahun \\
Menanam grain tiap acre & 4 jam per tahun \\
Menanam sugar beet tiap acre & 14 jam per tahun \\
\hline
\end{tabular}

Biaya lain adalah sebagai berikut:

\begin{tabular}{ll}
\hline Tiap sapi muda & $\$ 75$ per tahun \\
Tiap sapi perah & $\$ 150$ per tahun \\
Menanam grain tiap acre & $\$ 22.5$ per tahun \\
Menanam sugar beet tiap acre & $\$ 15$ per tahun \\
\hline
\end{tabular}

Biaya tenaga kerja untuk peternakan tersebut saat ini adalah $\$ 6000$ per tahun dan tersedia tenaga kerja selama 5500 jam. Di atas waktu yang tersedia tersebut akan dikenakan biaya tambahan $\$ 1.8$ per jam.

Setiap pengeluaran yang berkaitan dengan modal akan dibiayai oleh pinjaman selama 10 tahun dengan bunga 15\% per tahun. Bunga dan angsuran akan dibayar dalam 10 kali cicilan yang besarnya sama per tahun. Aliran kas diasumsikan tidak boleh negatif. Di akhir periode tahun kesepuluh, peternak tersebut tidak ingin mengurangi jumlah sapi perahnya lebih dari $50 \%$. Dia juga tidak ingin meningkatkan jumlah sapi perah tersebut lebih dari $75 \%$. Bagaimanakah peternak tersebut merencanakan penggunaan lahan selama sepuluh tahun mendatang?

\subsection{Model Pemrograman Linier}

Dari permasalahan yang diutarakan di sesi sebelumnya, dapat diformulasikan model Pemrograman Linier sebagai berikut:

Variabel:

$x_{i, t}=$ jumlah (dalam ton) grain yang ditanam di lahan grup $i$ pada tahun $t$ 


\section{Ramya Rachmawati, Siska Yosmar}

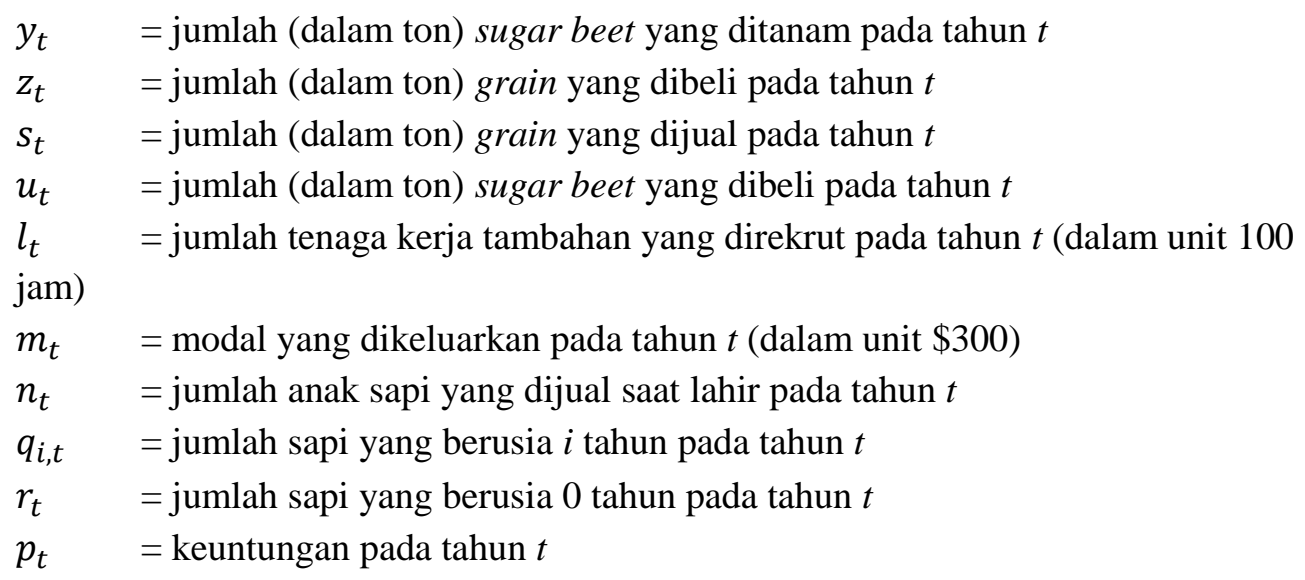

$i=1,2,3,4 ; t=1,2, \ldots, 10$ dan $j=1,2, \ldots, 12$. Pada penelitian ini, model yang diangkat adalah model diskret, di mana perubahan yang terjadi diasumsikan hanya satu kali setahun.

Kendala:

Kendala kontinuitas (keberlanjutan)

$$
\begin{gathered}
q_{1, t+1}=0,95 r_{t}, \text { untuk } t=1,2, \ldots, 9 \\
q_{2, t+1}=0,95 q_{1, t}, \text { untuk } t=1,2, \ldots, 9 \\
q_{j+1, t+1}=0,98 q_{j, t}, \quad \text { untuk semua } j>1, t=1,2, \ldots, 9 \\
r_{t}=\frac{1,1}{2} \sum_{j=2}^{12} q_{j, t}-n_{t}, \text { untuk semua } t
\end{gathered}
$$

Kondisi awal:

$q_{j, 1}=9,5$, untuk $j=1,2$

$q_{j, 1}=9,8$, untuk $j=3,4, \ldots, 12$

Akomodasi

$r_{t}+\sum_{j=1}^{11} q_{j, t} \leq 130+\sum_{k \leq t} m_{k}$, untuk semua $t$

Konsumsi grain

$$
\sum_{j=2}^{11} q_{j, t} \leq \frac{1}{0,6}\left(\sum_{i=1}^{4} x_{i, t}+z_{t}-s_{t}\right), \text { untuk semua } t
$$

Konsumsi sugar beet

$$
\sum_{j=2}^{11} q_{j, t} \leq \frac{1}{0,7}\left(y_{t}+u_{t}-v_{t}\right), \text { untuk semua } t
$$




\section{Ramya Rachmawati, Siska Yosmar}

Penanaman grain

$$
\begin{aligned}
& x_{1, t} \leq 1,1 \times 20 \text {, untuk semua } t \\
& x_{2, t} \leq 0,9 \times 30 \text {, untuk semua } t \\
& x_{3, t} \leq 0,8 \times 20 \text {, untuk semua } t \\
& x_{4, t} \leq 0,65 \times 10 \text {, untuk semua } t
\end{aligned}
$$

Kapasitas lahan

$$
\begin{aligned}
\frac{1}{1,1} x_{1, t}+\frac{1}{0,9} x_{2, t} & +\frac{1}{0,8} x_{3, t}+\frac{1}{0,65} x_{4, t}+\frac{1}{1,5} y_{t}+\frac{2}{3} r_{t}+\frac{2}{3} q_{1, t}+\sum_{j=2}^{11} q_{j, t} \\
& \leq 200, \text { untuk semua } t
\end{aligned}
$$

Kendala tenaga kerja (dalam unit 100 jam)

$$
\begin{aligned}
0,1 r_{t}+0,1 q_{1, t}+ & 0,42 \sum_{j=2}^{11} q_{j, t}+0,04\left(\frac{1}{1,1} x_{1, t}+\frac{1}{0,9} x_{2, t}+\frac{1}{0,8} x_{3, t}+\frac{1}{0,65} x_{4, t}\right) \\
& +\frac{0,14}{1,5} y_{t} \leq 55+l_{t}, \text { untuk semua } t
\end{aligned}
$$

Jumlah sapi perah di akhir periode

$$
\begin{gathered}
\sum_{j=2}^{11} q_{j, 10} \leq 175, \\
\sum_{j=2}^{11} q_{j, 10} \geq 50,
\end{gathered}
$$

Keuntungan

$p_{t}=$

$45 \times \frac{1,1}{2} \sum_{j=2}^{11} q_{j, t}+60 n_{t}$ (penjualan anak sapi betina) +

$180 q_{12, t}$ (penjualan sapi usia 12 tahun $)+555 \sum_{j=2}^{11} q_{j, t}$ (penjualan susu) +

$112,5 s_{t}$ (penjualan grain $)+87 v_{t}($ penjualan sugar beet $)-135 z_{t}$ (penjualan grain $)-$ $105 u_{t}$ (pembelian sugar beet) $-180 l_{t}-6000$ (tenaga kerja) $-75 r_{t}-$ $75 q_{1 t}$ (biaya pemeliharaan anak sapi betina) $150 \sum_{j=2}^{11} q_{j, t}$ (biaya pemeliharaan sapi perah) $-22,5\left(\frac{1}{1,1} x_{1, t}+\frac{1}{0,9} x_{2, t}+\frac{1}{0,8} x_{3, t}+\right.$ 
$\left.\frac{1}{0,65} x_{4, t}\right)$ (biaya grain) $-\frac{15}{1,5} y_{t}$ (biaya sugar beet) $59,77 \sum_{k \leq t} m_{k}$ (biaya modal) untuk semua $t$.

(Angsuran tiap tahun untuk pinjaman sebesar \$300 adalah \$59,77)

Keuntungan tidak boleh negatif

$$
p_{t} \geq 0 \text {, untuk semua } t
$$

Fungsi Tujuan

Maksimumkan

$$
\sum_{t=1}^{10} p_{t}
$$

Model ini memiliki 242 kendala dan 260 variabel.

\subsection{Solusi Optimal}

Simulasi model dalam penelitian ini dilakukan dengan menggunakan bahasa pemrograman Python 2.7 dan PuLP modeller.

Keuntungan maksimum yang diperoleh dalam kurun waktu 10 tahun adalah \$363 765 . Berikut ini perincian perencanaan tiap tahunnya

\begin{tabular}{ll}
\hline Tahun pertama & Tanam 22 ton grain di grup 1 \\
& Tanam 75 ton sugar beet \\
& Beli 37 ton grain \\
& Jual 6 ton sugar beet \\
& Jual 14 anak sapi betina (tersisa 39) \\
& Pinjam tambahan modal sebanyak 16 unit $\times \$ 300$ \\
\hline Keuntungan di tahun pertama adalah $\$ 28339$ \\
\hline Tahun kedua & Tanam 22 ton grain di grup 1 \\
& Tanam 76 ton sugar beet \\
& Beli 35 ton grain \\
& Jual 9 ton sugar beet \\
& Jual 38 anak sapi betina (tersisa 14) \\
\hline Keuntungan di tahun kedua adalah $\$ 28$ 924 \\
\hline Tahun ketiga & Tanam 22 ton grain di grup 1 \\
& Tanam 64 ton sugar beet \\
& Beli 50 ton grain \\
Beli 20 ton sugar beet
\end{tabular}




\section{Ramya Rachmawati, Siska Yosmar}

Jual 52 anak sapi betina (tersisa 14)

\begin{tabular}{|c|c|}
\hline \multicolumn{2}{|c|}{ Keuntungan di tahun ketiga adalah \$ 36379} \\
\hline Tahun keempat & $\begin{array}{l}\text { Tanam } 22 \text { ton grain di grup } 1 \\
\text { Tanam } 63 \text { ton sugar beet } \\
\text { Beli } 50 \text { ton grain } \\
\text { Beli } 21 \text { ton sugar beet } \\
\text { Jual } 53 \text { anak sapi betina (tersisa 13) }\end{array}$ \\
\hline Keuntungan di ti & in keempat adalah \$ 36694 \\
\hline Tahun kelima & $\begin{array}{l}\text { Tanam } 22 \text { ton grain di grup } 1 \\
\text { Tanam } 63 \text { ton sugar beet } \\
\text { Beli } 51 \text { ton grain } \\
\text { Beli } 22 \text { ton sugar beet } \\
\text { Jual } 54 \text { anak sapi betina (tersisa } 13 \text { ) }\end{array}$ \\
\hline
\end{tabular}

Keuntungan di tahun kelima adalah \$ 36585

\begin{tabular}{|c|c|}
\hline Tahun keenam & $\begin{array}{l}\text { Tanam } 22 \text { ton grain di grup } 1 \\
\text { Tanam } 62 \text { ton sugar beet } \\
\text { Beli } 51 \text { ton grain } \\
\text { Beli } 23 \text { ton sugar beet } \\
\text { Jual } 54 \text { anak sapi betina (tersisa 13) }\end{array}$ \\
\hline \multicolumn{2}{|c|}{ Keuntungan di tahun keenam adalah \$ 37084} \\
\hline Tahun ketujuh & $\begin{array}{l}\text { Tanam } 22 \text { ton grain di grup } 1 \\
\text { Tanam } 75 \text { ton sugar beet } \\
\text { Beli } 51 \text { ton grain } \\
\text { Beli } 11 \text { ton sugar beet } \\
\text { Jual } 67 \text { anak sapi betina (tidak ada sisa) }\end{array}$ \\
\hline \multicolumn{2}{|c|}{ Keuntungan di tahun ketujuh adalah $\$ 40033$} \\
\hline Tahun kedelapan & $\begin{array}{l}\text { Tanam } 22 \text { ton grain di grup } 1 \\
\text { Tanam } 86 \text { ton sugar beet } \\
\text { Beli } 51 \text { ton grain } \\
\text { Jual } 68 \text { anak sapi betina (tidak ada sisa) }\end{array}$ \\
\hline \multicolumn{2}{|c|}{ Keuntungan di tahun kedelapan adalah $\$ 42084$} \\
\hline Tahun kesembilan & $\begin{array}{l}\text { Tanam } 22 \text { ton grain di grup } 1 \text { dan } 14 \text { ton di grup } 2 . \\
\text { Tanam } 78 \text { ton sugar beet } \\
\text { Beli } 31 \text { ton grain } \\
\text { Jual } 62 \text { anak sapi betina (tidak ada sisa) }\end{array}$ \\
\hline \multicolumn{2}{|c|}{ Keuntungan di tahun kesembilan adalah \$ 40405} \\
\hline Tahun kesepuluh & $\begin{array}{l}\text { Tanam } 22 \text { ton grain di grup } 1 \\
\text { Tanam } 118 \text { ton sugar beet }\end{array}$ \\
\hline
\end{tabular}




\begin{tabular}{l}
\hline Beli 39 ton grain \\
Jual 47 ton sugar beet \\
Jual 56 anak sapi betina (tidak ada sisa) \\
\hline
\end{tabular}

Keuntungan di tahun kesepuluh adalah \$ 38635

Solusi optimal memperlihatkan bahwa di tahun pertama dibutuhkan tambahan modal untuk akomodasi sapi sebanyak 16 unit.

\section{Kesimpulan}

Berdasarkan demonstrasi model dapat disimpulkan bahwa masalah perencanaan dalam bidang pertanian/peternakan dapat diselesaikan dengan pendekatan pemrograman linier. Parameter yang diangkat dalam penelitian ini masih bersifat deterministik. Oleh karena dalam dunia nyata parameter yang terlibat biasanya bersifat probabilistik, maka perlu dilakukan penelitian lebih lanjut. Selain itu, komoditas pangan yang diangkat dalam penelitian ini terbatas hanya pada grain dan sugar beet, tentunya tanaman ini dapat disesuaikan dengan tanaman yang cocok untuk ditanami di lokasi peternakan tertentu. Perencanaan yang baik di bidang pertanian/peternakan tentunya akan membantu peternak memperoleh keuntungan yang optimal dan mendukung program pemerintah untuk mengembangkan sektor ini.

\section{DAFTAR PUSTAKA}

Hillier, FS \& Lieberman GJ (2005). Introduction to Operations Research. The McGraw-Hill Companies, Inc.

Sudono, A., R. F. Rosdiana, \& B. S. Setiawan. (2003). Beternak Sapi Perah Secara Intensif. Agromedia Pustaka, Jakarta

Williams, H. P. (2013). Model Building in Mathematical Programming. John Wiley \& Sons. 